\title{
PERLINDUNGAN HUKUM ATAS DATA PRIBADI BAGI KONSUMEN DALAM KLAUSULA EKSONERASI TRANSPORTASI ONLINE
}

\author{
Muhammad Saiful Rizal, Yuliati, Siti Hamidah \\ Magister Ilmu Hukum, Program Pasca Sarjana Universitas Brawijaya \\ Jl. MT. Haryono No 169 Malang, Jawa Timur, Indonesia \\ Email: msrizal150@gmail.com
}

\begin{abstract}
The exoneration clause is still used in the online transportation agreement clause, when the user registers. This has an impact on the legal uncertainty for consumers in the protection of their personal data managed by the application business actors. This study aims to analyze the presence or absence of violations in Article 18 of the Consumer Protection Law related to exoneration clauses in online transportation, and forms of legal protection of consumer personal data in standard contracts. This research is a normative legal research, with a statue approach and comparative approach. The results of this study are that application business actors have transferred the responsibility of protecting consumer personal data which should be the obligation of the application business actor. The application of exoneration clauses carried out by application businesses is very detrimental to consumers by feeling insecure and comfortable in using online transportation services. Forms of legal protection from the government related to consumer personal data in using online transportation services with the obligation of businesses to revise and replace losses suffered by consumers.
\end{abstract}

\section{Keywords : Exoneration Clause, Consumer Protection, Personal Data}

\begin{abstract}
Abstrak
Klausula eksonerasi masih digunakan dalam klausula perjanjian trasnportasi online, ketika pengguna melakukan registrasi. Hal ini berdampak adanya ketidakpastian hukum kepada konsumen dalam perlindungan data pribadinya yang dikelola oleh pelaku usaha aplikasi. Penelitian ini bertujuan untuk menganalisis ada tidaknya pelanggaran dalam Pasal 18 UU Perlindungan Konsumen terkait klausula eksonerasi dalam transportasi online, dan bentuk perlindungan hukum data pribadi konsumen dalam kontrak baku. Penelitian ini merupakan penelitian hukum normatif, dengan pendekatan perundang-undangan dan pendekatan perbandingan. Hasil penelitian ini adalah pelaku usaha aplikasi telah mengalihkan tanggung jawab perlindungan data pribadi konsumen yang seharusnya merupakan kewajiban pelaku usaha aplikasi. Penerapan klausula eksonerasi yang dilakukan oleh pelaku usaha aplikasi sangat merugikan konsumen dengan merasa tidak aman dan nyaman dalam menggunakan layanan transportasi online. Bentuk perlindungan hukum dari pemerintah terkait data
\end{abstract}


pribadi konsumen dalam menggunakan jasa transportasi online dengan kewajiban pelaku usaha untuk merevisi dan mengganti kerugian yang dialami oleh konsumen.

\section{Kata Kunci : Klausula Eksonerasi, Perlindungan Konsumen, Data Pribadi}

\section{A. PENDAHULUAN}

Penggunaan aplikasi online berbasis tranportasi (Go-jek dan Grab) harus menggunakan nomor telpon dan atau email dalam proses registrasi. Para konsumen juga harus menyetujui segala bentuk peraturan baik syarat dan penggunaan dan juga kebijakan privasi yang telah ditentukan oleh pihak aplikasi online berbasis transportasi ini yang mana otomatis perjanjian ini menjadi suatu perjanjian yang baku. Kesepakatan antara konsumen dan pihak aplikasi online terjadi setelah konsumen mendownload dan melakukan registrasi menggunakan aplikasi online berbasis transportasi yang secara otomatis hal itu akan menjadi suatu kesepakatan antar keduanya yang meliputi syarat penggunaan dan juga kebijakan privasi yang ada di dalam aplikasi tersebut.

Kesepakatan atau perjanjian yang baik apabila terjadi sesuatu yang mengenai data pribadi yang merugikan para konsumen, maka hal tersebut merupakan tanggung jawab pihak aplikasi online berbasis transportasi. Akan tetapi dalam perlindungannya mengenai data pribadi yang telah termuat dalam kesepakatan baku (syarat penggunaan dan kebijakan privasi) pihak aplikasi online berbasis transportasi menerapkan bentuk pengalihan pertanggungjawaban atau syarat eksonerasi yang menyatakan bahwa pihak aplikasi online tidak sepenuhnya bertanggung jawab apabila terjadi penipuan yang mengatasnamakan pihak aplikasi, ataupun modus penipuan yang disalahgunakan oleh pihak ketiga dan juga membatasi tanggung jawab pihak aplikasi dalam mengelola data konsumennya, secara tidak langsung pihak aplikasi online berbasis transportasi menyatakan bahwa risiko ditanggung sendiri atau adanya peran aktif para konsumen pengguna jasa online tersebut untuk menjaga keamanan data diri mereka sendiri. ${ }^{1}$

Keberadaan kontrak elektronik pada dasarnya merupakan inisiatif para pelaku usaha untuk merangkum perjanjian agara menjadi lebih efektif dan efisien. Hal ini juga berdasarkan pada asas kebebasan berkontrak yang digunakan secara berlebihan oleh pelaku usaha agar mendapat keuntungan bagi dirinya sehingga konsumen yang berada dalam posisi yang lebih lemah menjadi sangat dirugikan dengan adanya klausula eksonerasi dalam kontrak elektronik ini.

${ }^{1}$ Dalam Disclaimer salah satu aplikasi online berbasis transportasi menyatakan : "Kami tidak dapat l`sepenuhnya menjamin bahwa sistem kami tidak dapat ditembus sama sekali akibat adanya virus, malware, gangguan atau kejadian luar biasa termasuk akses tanpa otorisasi oleh pihak ketiga. Anda tidak boleh mengungkapkan sandi akun anda kepada siapapun dan harus senantiasa menjaga keamanan perangkat yang anda gunakan." 
Adanya klausula eksonerasi dalam ketentuan aplikasi online berbasis transportasi ini menunjukkan bahwa pelaku usaha tidak secara maksimal untuk bertanggung jawab dalam menjaga kerahasiaan data para konsumennya. Klausula Eksonerasi juga merupakan sarana bagi para pelaku usaha transportasi berbasis online untuk menjadi exit door atau jalan keluar dalam pertanggungjawaban yang seharusnya menjadi tanggung jawab para pelaku usaha. Karena para pengguna aplikasi online berbasis transportasi yang menggunakan telepon pintar dianggap tahu, memahami, dan menyepakati aturan dari pihak aplikasi. Akan tetapi banyak konsumen yang tidak menyadari betapa pentingnya perjanjian baku dalam mewujudkan hak dan kewajiban antara keduanya.

Pasal 18 ayat (1) a Undang-Undang Nomor 8 Tahun 1999 Tentang Perlindungan Konsumen (untuk selanjutnya disebut UU No. 8 Tahun 1999) di dalamnya menyatakan bahwa "Pelaku usaha dalam menawarkan barang dan/atau jasa yang ditujukan untuk diperdagangkan dilarang membuat atau mencantumkan klausula baku pada setiap dokumen dan/atau perjanjian apabila: 1 . menyatakan pengalihan tanggung jawab pelaku usaha".

Klausula yang digunakan dalam aplikasi online berbasis transportasi ini telah memenuhi ketentuan di atas yang termuat dalam kebijakan privasi dengan adanya klausula eksonerasi yang menyatakan pengalihan pertanggungjawaban dengan tidak melindungi atau bertanggung jawab secara penuh terhadap data pribadi para konsumennya. Perbuatan yang telah dilakukan oleh para pelaku usaha tersebut juga menjadi batal demi hukum sebagaimana dalam ketentuan UU No. 8 Tahun 1999 kelanjutan dalam pasal di atas apabila dilakukan pencantuman klusula baku dalam pengalihan pertanggungjawaban tersebut maka, akan batal demi hukum. Sesuai dengan Pasal 18 ayat (3) UU No. 8 Tahun 1999 menyatakan bahwa "Setiap klausula baku yang telah ditetapkan oleh pelaku usaha pada dokumen atau perjanjian yang memenuhi ketentuan sebagaimana dimaksud pada ayat (1) dan ayat (2) dinyatakan batal demi hukum."

Klausula yang telah terjadi dalam hal ini apakah akan menjadi semudah itu batal demi hukum dalam jasa transportasi online yang di dalam perjanjiannya seharusnya telah dianggap tidak terjadi atau batal demi hukum, akan tetapi para konsumen yang telah melakukan pendaftaran ataupun registrasi sudah secara otomatis menyetujui segala sesuatu yang ada di dalam perjanjiannya. Begitu pula, bagaimana dengan perlindungan hukum data pribadi konsumen yang telah dikelola oleh pelaku usaha aplikasi yang menggunakan jasa transportasi online tersebut. Pengguna jasa transportasi online perlu mendapatkan prioritas dan pelayanan yang baik dari pemerintah maupun penyedia jasa transportasi online dan juga perlindungan hukum atas hak-hak konsumen sebagai pengguna jasa transportasi online untuk lebih mendapatkan kepastian hukum. Agar tidak menimbulkan kerugian kepada konsumen, baik kerugian secara materil maupun kerugian immateriil.

Oleh sebab itu penulis melihat ada sebuah masalah di dalam ketentuan klausula eksonerasi (syarat penggunaan dan kebijakan privasi) aplikasi online berbasis transportasi yang apabila dikaitkan dengan ketentuan Pasal 18 ayat (1) a UU No. 8 Tahun 1999 tidak sesuai dan menjadi kekaburan hukum karena tidak adanya kepastian hukum bagi konsumen 
dalam perlindungan data pribadi mereka yang telah digunakan oleh pelaku usaha aplikasi dalam perjanjiannya. Sebagaimana dalam perlindungan konsumen yang mengutamakan kenyamanan, keamanan dan keselamatan konsumen dalam mengkonsumsi barang dan/ atau jasa dari aplikasi berbasis online tersebut. Oleh karenanya bagaimana upaya hukum perlindungan data pribadi yang tepat bagi para konsumen yang telah melakukan suatu perjanjian yang di dalamnya tidak memberikan perlindungan secara menyeluruh, justru hal ini menjadi jalan keluar bagi para pelaku usaha dalam pertanggungjawabannya.

\section{B. RUMUSAN PERMASALAHAN}

Berdasarkan latar belakang di atas, maka penulis mengambil fokus permasalahan : a) Apakah klausula eksonerasi dalam perjanjian transportasi online melanggar ketentuan dalam Pasal 18 UU No. 8 Tahun 1999; dan b) Bagaimana bentuk perlindungan hukum data pribadi konsumen dalam kontrak baku berklausula eksonerasi menurut Pasal 18 UU No. 8 Tahun 1999.

\section{METODE PENELITIAN}

Jenis penelitian yang digunakan dalam meneliti permasalahan ini ialah penelitian hukum normatif. Penelitian hukum normatif adalah suatu prosedur penelitian ilmiah untuk menemukan kebenaran berdasarkan logika keilmuan hukum dari sisi normatifnya. ${ }^{2}$ Pendekatan penelitian yang digunakan oleh peneliti adalah pendekatan perundang-undangan (statue approach) dan pendekatan perbandingan (comparative approach). Pendekatan perundang-undangan menjadi fokus sekaligus tema sentral dalam suatu penelitian. ${ }^{3}$ Studi perbandingan hukum merupakan kegiatan untuk membandingkan antara hukum negara satu dengan hukum negara lain atau hukum dari suatu waktu tertentu dengan hukum dari waktu yang lain. ${ }^{4}$ Bahan hukum yang dipergunakan oleh peneliti dalam melakukan penelitian ini baik bahan hukum primer, bahan hukum sekunder dan bahan hukum tersier diperoleh dari: Pusat Dokumentasi Ilmu Hukum (PDIH) Fakultas Hukum Universitas Brawijaya Malang; Perpustakaan Pusat Universitas Brawijaya Malang; Perpustakaan Umum Kota Malang; Penelusuran Pustaka Pribadi; dan Penelusuran di situs-situs Internet.

\section{PEMBAHASAN}

\section{Klausula Eksonerasi Dalam Perjanjian Transportasi Online Berdasarkan Pasal} 18 UU No. 8 Tahun 1999

\footnotetext{
${ }^{2}$ Johnny Ibrahim, Teori \& Metodologi Penelitian Hukum Normatif, (Malang : Bayumedia Publishing,
} 2006), hlm. 57

${ }^{3}$ Ibid, hlm. 302-303

${ }^{4}$ Peter Mahmud Marzuki, Penelitian Hukum, (Jakarta : Kencana Prenada Media Group, 2005), hlm. 93 
Perjanjian atau perikatan melalui media elektronik yang berupa kontrak elektronik dengan berkembangnya teknologi dan informasi digunakan dalam jasa transportasi secara online. Kontrak elektronik ini hampir semuanya berupa klausula baku yang telah disiapkan oleh pelaku usaha guna untuk mempermudah dan mempersingkat waktu agar tidak terlalu lama dalam mencapai kesepakatan dan dapat digunakan dalam waktu yang relatif lebih cepat. Sebagaimana jasa transportasi online yang merupakan suatu kebutuhan hidup masyarakat agar lebih mudah dan efisien dalam mencapai tujuannya. Kontrak elektronik dalam transportasi online berisi ketentuan pengguna dan kebijakan privasi yang harus disetujui oleh konsumen sebagai pengguna jasa transportasi online.

Penggunaan aplikasi online berbasis transportasi dalam telepon seluler, dapat berupa persetujuan konsumen dengan satu kali klik (single click) atau dua kali klik (double click). Dengan melakukan klik tersebut konsumen memberikan akses terhadap data dan informasi milik konsumen kepada operator aplikasi online. Konsumen dan siapapun yang menggunakan teknologi aplikasi tersebut, dianggap tunduk dan patuh pada syarat penggunaan dan kebijakan privasi (privacy policy) yang diberlakukan oleh pelaku usaha penyelenggara teknologi aplikasi dalam klausulanya yang telah disetujui oleh konsumen. Kebijakan privasi yang ada dalam situs website atau aplikasi tersebut berlaku selayaknya ketentuan dalam perjanjian tertulis antara konsumen dengan pelaku usaha aplikasi. Namun, mayoritas masyarakat yang secara langsung memberikan atau melakukan "klik" sebagai tanda persetujuan tanpa membaca kebijakan privasi secara lengkap dikarenakan hanya agar dapat mengunduh aplikasi. Hal ini terjadi karena selain kebutuhan akan transportasi yang cepat dan mudah, sulitnya konsumen dalam memahami klausula baku yang tertuang dalam syarat dan penggunaan dan kebijakan privasi yang banyak dari konsumen belum memahami isi dalam ketentuan tersebut ditambah juga klusula baku yang dipersiapkan oleh pelaku usaha aplikasi tersebut sangatlah banyak atau berlembarlembar. Sehingga konsumen enggan dan sulit untuk memahami ketentuan yang telah dipersyaratkan oleh pelaku usaha aplikasi. Selain juga karena faktor kebutuhan akan jasanya.

Dalam kebijakan privasi data pribadi konsumen harus diserahkan kepada pelaku usaha aplikasi. Pelaku usaha aplikasi bertanggung jawab untuk melindungi data pribadi yang menjadi konsumennya. Sudah ada pelaku usaha aplikasi dalam kebijakan privasi juga menyatakan kepatuhan kepada Data Protection Act (Undang-Undang Perlindungan Data Pribadi) yang berlaku di Indonesia. Namun, perlindungan data pribadi belum diatur secara khusus di Indonesia, kecuali yang diatur dalam UU No. 11 Tahun 2008.

Data pribadi dalam jasa transportasi online baik Go-jek maupun Grab merupakan sebuah persyaratan bagi konsumen untuk menggunakan aplikasinya. Data pribadi dalam Go-jek meliputi alamat surat elektronik (email), nama, nomor telepon ,sandi akun dan juga nama bank dan nama pemegang rekening yang menggunakan layanan Go-pay.

\footnotetext{
${ }^{5}$ Undang-Undang Nomor 11 Tahun 2008 tentang Informasi dan Transaksi Elektronik
} 
Sedangkan data pribadi yang dikumpulkan oleh Grab lebih luas seperti nama, alamat dan kota tempat tinggal, kata sandi (password), usia, nomor telepon, nomor faks, rincian bank, rincian kartu kredit, jenis kelamin, status kependudukan, latar belakang keuangan, kepentingan pribadi, alamat email, pekerjaan anda, foto anda, informasi tentang anda yang diberikan kepada Grab dalam bentuk formulir. ${ }^{6}$ Dalam mengakases data pribadi konsumen, Grab juga dapat mengakses data pribadi yang sensitif seperti nomor kartu identitas anda, nomor SIM, nomor akte kelahiran, nomor paspor, ras, asal etnis, tanggal lahir, status perkawinan, latar belakang pendidikan, dan data yang berkaitan dengan kesehatan, agama atau kepercayaan sejenis lainnya ${ }^{7}$. Informasi-informasi ini dapat dipergunakan berbagai macam keperluan yang pada dasarnya digunakan untuk meningkatkan kualitas pelayanan situs maupun aplikasi, tetapi kadangkala juga digunakan untuk promo dan pemasaran.

Berikut salah satu contoh bentuk privacy policy perusahaan Go-jek dan Grab yang merupakan perusahaan penyedia jasa transportasi online berbasis aplikasi :

Anda juga menyatakan bahwa anda memiliki hak untuk membagikan seluruh informasi yang telah anda berikan kepada kami dan untuk memberikan hak kepada kami untuk menggunakan dan membagikan informasi tersebut kepada penyedia layanan.

Sangat penting bahwa konsumen harus benar-benar sadar akan disclaimer dalam kebijakan privasinya. UU No. 8 Tahun 1999 memberikan perlindungan kepada konsumen yang melakukan perikatan atau perjanjian melalui kontrak elektronik agar tetap sesuai dengan ketentuan perundang-undangan. Adanya klausula baku yang tertuang dalam kontrak elektronik antara konsumen dengan pelaku usaha aplikasi online berbasis transportasi ini harus sesuai dengan ketentuan yang berlaku dengan tidak adanya pengalihan pertanggungjawaban dari pelaku usaha aplikasi kepada konsumennya. Sehingga konsumen akan mendapat kepastian hukum apabila terjadi sesuatu atau hal yang merugikan konsumen dalam mengkonsumsi barang dan atau jasa dari pelaku usaha aplikasi.

Di sisi lain, UU No. 11 Tahun 2008 telah memberikan perlindungan terhadap konsumen dari penggunaan data pribadi tanpa izin pemiliknya. Konsumen harus memperhatikan apakah data pribadinya digunakan pelaku usaha aplikasi sesuai dengan tujuan atau kepentingan konsumen. Konsumen harus membaca syarat penggunaan dan kebijakan privasi aplikasi yang ia gunakan, agar dapat meminta pertanggungjawaban dari pelaku usaha aplikasi jika terjadi penggunaan data pribadi tanpa sepengetahuan konsumen.

${ }^{6}$ Grab, Pengumpulan Data Pribadi, Kebijakan Privasi Grab, (https://www.grab.com/id/privacy/ di akses pada 15 Oktober 2018), (online)

${ }^{7}$ Ibid. 
Ketika konsumen pengguna jasa transportasi online menyetujui klausula eksonerasi dari pelaku usaha aplikasi, maka konsumen secara otomatis juga akan menyetujui ketentuan penggunaan data pribadi yang telah diberikan oleh pelaku usaha penyedia barang dan atau jasa. Persetujuan tersebut timbul masalah ketika pihak penyedia barang dan atau jasa yang menerapkan syarat eksonerasi dalam syarat penggunaan dan kebijakan privasi dengan menyalahgunakan data pribadi konsumennya. Sebagai contoh adanya teror, ataupun intimidasi sampai pelecehan seksual yang dilakukan oleh driver sebagai penyedia jasa online yang menggunakan nomor telepon pengguna jasa yang telah disediakan oleh pelaku usaha aplikasi tersebut. Berikut skema perolehan dan pengolahan data pribadi yang didapat penyedia jasa dari pelaku usaha aplikasi:

\section{Gambar 3.2}

Tentang Skema Alur Perolehan dan Pengolahan Data Pribadi

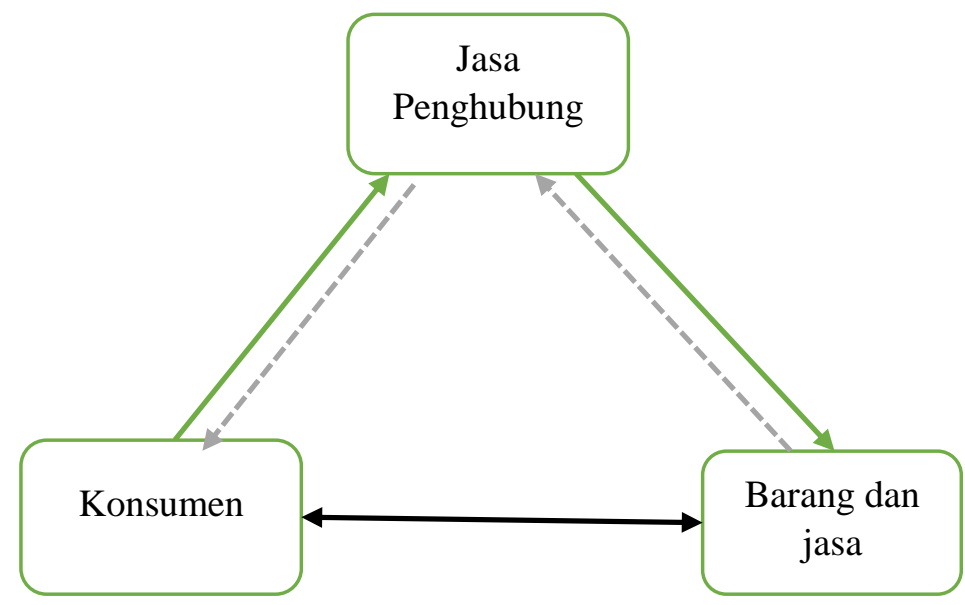

Gambar di atas menunjukkan konsumen telah setuju untuk memberikan data pribadi tersebut kepada penyedia jasa maupun barang dengan melalui jasa penghubung dengan menggunakan sebuah aplikasi. Selanjutnya akan diproses dalam pemenuhan prestasi yang sudah terjadi antara konsumen dengan penyedia jasa dan barang. Konsumen dituntut untuk lebih kritis dalam menggunakan segala bentuk produk yang dikonsumsinya baik berupa jasa maupun barang. Terlebih dengan kemajuan teknologi, konsumen seharusnya lebih teliti dalam memilih barang yang wujudnya masih dalam bentuk digital yang ditawarkan melalui aplikasi.

Dalam kontrak elektronik pada jasa transportasi online di dalamnya memuat adanya klausula eksonerasi terkait kewajiban pelaku usaha dalam memberikan perlidungan data pribadi kepada konsumennya. ${ }^{8}$ Tidak hanya itu saja konsumen juga harus melindungi data pribadinya setelah menggunakan atau mengkonsumsi jasanya. ${ }^{9}$

${ }^{8}$ Berikut contoh klausula tersebut dalam kebijakan privasi jasa transportasi online tersebut : "Kami akan memberlakukan upaya dan langkah yang terbaik untuk melindungi dan mengamankan data dan informasi pribadi anda. Akan tetapi kami tidak dapat sepenuhnya menjamin bahwa sistem kami tidak akan dapat ditembus 
Pengalihan pertanggungjawaban tersebut sangat merugikan masyarakat sebagai konsumen yang menggunakan jasa transportasi online. Konsumen tidak mendapat perlindungan secara penuh terhadap datanya yang dikelola dan digunakan oleh pelaku usaha aplikasi. Konsumen juga tidak mendapat jaminan pertanggungjawaban dari pelaku usaha terkait data pribadinya setelah menggunakan aplikasi tersebut.

Hal ini membuat konsumen menjadi terancam atas kenyamanan dan keselamatannya dalam menggunakan jasa tersebut. Karena banyak penyalahgunaan yang terjadi akibat data pribadi kita yang digunakan oleh orang yang tidak bertanggung jawab termasuk driver ataupun orang ketiga yang menjadikan data pribadi kita sebagai media pemasaran maupun promo.

Perjanjian baku yang di dalamnya terdapat pengalihan pertanggungjawaban selain sangat merugikan konsumen, dapat juga menjadi exit door atau jalan keluar dalam pertanggungjawaban yang seharusnya menjadi tanggung jawab para pelaku usaha. Oleh karenanya sebagaimana dalam Pasal 18 Ayat (1) huruf a UU No. 8 Tahun 1999 menyatakan sebagai berikut $:^{10}$

(1) Pelaku usaha dalam menawarkan barang dan/atau jasa yang ditujukan untuk diperdagangkan dilarang membuat atau mencantumkan klausula baku pada setiap dokumen dan/atau perjanjian apabila :

a. menyatakan pengalihan tanggung jawab pelaku usaha;

Dalam pasal di atas penulis akan menganalisis klausula yang menyatakan pengalihan tanggung jawab. Pengalihan tanggung jawab dalam klausula baku yang dilarang dalam pasal ini, karena dengan adanya pengalihan tanggung jawab maka pelaku usaha dapat lepas dari tanggung jawab yang seharusnya ia penuhi kepada konsumennya. Selain dalam perjanjian tersebut merupakan klausula baku yang mana kedudukan para pihak tidak seimbang, di dalamnya juga memiliki ketentuan yang dapat melepaskan diri dari tanggung jawabnya. Kedudukan dalam perjanjian ini tidak seimbang antara konsumen sebagai pihak yang lemah yang tidak bebas dalam menentukan apa yang diinginkan dalam perjanjian tersebut. Di sisi lain pelaku usaha berada dalam posisi yang kuat selain menentukan kontrak baku ia juga dapat melepas atau mengalihkan pertanggungjawabannya dengan adanya klausula eksonerasi yang telah ia sediakan sebelumnya. Maka dapat dipastikan bahwa perjanjian tersebut memuat klausula-klausula yang meguntungkan bagi pelaku usaha atau dapat juga meringankan serta menghapuskan

sama sekali akibat adanya virus, malware, gangguan atau kejadian luar biasa termasuk akses tanpa otorisasi oleh pihak ketiga. Anda tidak boleh mengungkapkan sandi akun anda kepada siapapun dan harus senantiasa menjaga keamanan perangkat yang anda gunakan.”

${ }^{9}$ Kami tidak bertanggung jawab atas penyimpanan data yang telah dimiliki oleh penyedia layanan di luar kepentingannya, dan atas dasar tersebut anda setuju untuk membela, memberikan ganti rugi dan membebaskan kami dari segala tanggung jawab atas segala penyalahgunaan informasi pribadi anda oleh penyedia layanan.

${ }^{10}$ Pasal 18 ayat (1) Undang-Undang Nomor 8 Tahun 1999 Tentang Perlindungan Konsumen. 
beban-beban atau kewajiban-kewajiban tertentu yang seharusnya menjadi tanggung jawab pelaku usaha.

Klausula dalam aplikasi online berbasis transportasi ini telah memenuhi ketentuan di atas yang termuat dalam kebijakan privasi dengan menyatakan bentuk pengalihan pertanggungjawaban yang mereka lakukan dengan tidak melindungi atau bertanggung jawab secara penuh terhadap data pribadi para konsumennya. Pelaku usaha idealnya menjamin hak-hak konsumennya, namun yang dilakukan seringkali mereduksi kewajibankewajibannya kepada konsumen, misalnya dengan mencantumkan klausula baku yang menjadikan posisi konsumen menjadi lemah dan tidak mempunyai daya tawar yang memadai dihadapan pelaku usaha. Sehingga banyak terjadi kerugian yang dialami oleh konsumen terkait dengan adanya pencantuman klausula baku tersebut.

Klausula baku yang mencantumkan pengalihan tanggung jawab pelaku usaha dalam pasal selanjutnya Pasal 18 Ayat (3) UU No. 8 Tahun 1999 manyatakan "Setiap klausula baku yang telah ditetapkan oleh pelaku usaha pada dokumen atau perjanjian yang memenuhi ketentuan dalam Pasal 18 Ayat (1) dan 2 dinyatakan batal demi hukum”.

Dalam frasa batal demi hukum di atas mengindikasikan bahwa perjanjian atau perikatan yang di dalamnya ada klausul eksonerasi dan ketentuan yang dilarang dalam Pasal 18 Ayat (1) dan (2) akan menjadi batal demi hukum. Suatu dokumen atau perjanjian yang bersifat batal demi hukum, memiliki arti bahwa dokumen atau perjanjian itu tidak pernah ada dan tidak pula terjadi sebuah perjanjian ataupun perikatan. Dalam perjanjian yang dinyatakan batal demi hukum hakim wajib karena jabatannya menyatakan bahwa tidak pernah ada suatu perjanjian ataupun perikatan. ${ }^{11}$ Pelaku usaha aplikasi juga wajib merevisi dokumen atau perjanjian yang di dalamnya terdapat pencantuman klausula baku dengan ketentuan yang ada di dalam Undang-Undang Nomor 8 Tahun 1999 Tentang Perlindungan Konsumen. Ketentuan di atas menjelaskan bahwa perjanjian atau kontrak elektronik yang menjadi kontrak baku harus memenuhi ketentuan di atas. Sehingga akan ada batasan-batasan bagi para pelaku usaha yang menggunakan perjanjian baku agar tetap sesuai dengan Undang-Undang Perlindungan Konsumen.

Dalam ketentuan pasal di atas memberikan kepastian hukum bagi konsumen yang menggunakan jasa transportasi online dengan memberikan perlindungan yang jelas kepada konsumen dengan mengharuskan pelaku usaha bertanggung jawab atas data pribadi konsumen dan melindungi privasi konsumen selama menggunakan aplikasi tersebut. Pelaku usaha aplikasi juga diwajibkan merevisi ketentuan dalam kebijakan privasinya agar sesuai dengan ketentuan di atas dan juga dengan ketentuan-ketentuan selain Pasal 18 Undang-Undang Nomor 8 Tahun 1999 Tentang Perlindungan Konsumen.

Kepastian hukum merupakan instrumen penting dalam terciptanya hukum atau ketentuan yang pasti dan adil, sehingga dengan adanya kepastian hukum suatu aturan atau

\footnotetext{
${ }^{11}$ R. Subekti, Hukum Perjanjian, (Jakarta : PT.Intermessa, 1996) hlm. 22
} 
ketetapan dapat memberikan suatu alasan yang jelas dan terang agar terhindar dari kekaburan hukum dan berjalan sebagaimana fungsinya. Dalam transportasi online ini pelaku usaha aplikasi harus memberikan kepastian hukum dengan jelas dalam memberikan hak-hak konsumen dan melakukan kewajibannya dengan bertanggung jawab secara penuh terhadap data pribadi yang telah diperoleh dari konsumen pengguna jasa tranportasi online. Sehingga konsumen yang merasa dirugikan dengan pengelolaan atau penggunaan data pribadi yang dilakukan oleh pelaku usaha aplikasi dapat meminta kepastian hukum dengan memberikan perlindungan dan ganti rugi yang timbul akibat penyalahgunaan data pribadi konsumen.

\section{Perlindungan Hukum Data Pribadi Konsumen Dalam Klausula Eksonerasi Transportasi Online Berdasarkan Pasal 18 UU No. 8 Tahun 1999}

\section{a. Perlindungan Hukum Preventif}

Upaya preventif dalam perlindungan data pribadi konsumen yang digunakan dalam transportasi online dengan melalui pencegahan dalam UU No. 8 Tahun 1999 dalam Pasal 18 Ayat (1) bertujuan agar pelaku usaha berhati-hati dalam membuat perjanjian dalam bentuk baku agar tidak menimbulkan kerugian bagi konsumen. Selain itu dalam Pasal 29 Ayat (1) UU No. 8 Tahun $1999^{12}$ menyatakan adanya keterlibatan pemerintah dalam pembinaan penyelenggaraan perlindungan konsumen berdasarkan ketentuan pasal ini. Dasarnya ialah pada kepentingan yang amanatkan oleh pembukaan "Undang-Undang Dasar 1945" bahwa kehadiran negara antara lain, untuk mensejahterakan rakyatnya. Amanat ini dijabarkan dalam "Pasal 33 UndangUndang Dasar 1945' dan Garis-Garis Besar Haluan Negara (GBHN) yang menyatakan pembangunan ekonomi harus melindungi kepentingan konsumen, serta peraturan perundang-undangan lainnya.

Tanggung jawab pengawasan dan perlindungan, telah ditegaskan dalam Pasal 30 ayat (1) UU No. 8 Tahun 1999 menyatakan bahwa "Pengawasan terhadap penyelenggaraan perlindungan konsumen serta penerapan ketentuan peraturan perundang-undangannya diselenggarakan oleh pemerintah, masyarakat, dan lembaga perlindungan konsumen swadaya masyarakat".

Lebih jelasnya bentuk pengawasan tersebut diatur dalam pasal 8 ayat (1) Peraturan Pemerintah Nomor 58 Tahun 2001 Tentang Pembinaan dan Pengawasan Penyelenggaraan Perlindungan Konsumen yang menyebutkan bahwa "Pengawasan oleh pemerintah dilakukan terhadap pelaku usaha dalam memenuhi standar mutu produksi barang dan atau jasa, pencantuman label dan klausula baku, serta pelayanan purna jual barang dan atau jasa".

12 Pemerintah bertanggung jawab atas pembinaan penyelenggaraan perlindungan konsumen yang menjamin diperolehnya hak konsumen dan pelaku usaha serta dilaksanakannya kewajiban konsumen dan pelaku usaha. 
Terlebih lagi dalam memberikan perlindungan yang lebih baik dalam langkah preventif ini dapat diberlakukan sebagaimana yang berlaku di negeri Belanda dengan berlakunya "Nieuw Burgerlijk Wetboek (NBW) Tahun 1992" yang menetapkan adanya komisi yang sangat melindungi konsumen terutama konsumen dalam perjanjian baku yang diatur dalam Artikel 6:5.1.2 Nieuw Burgerlijk Wetboek, yaitu sebagai berikut:

"Een standaardregeling wordt vastgesteld, gewijzigd en ingetrokken door een daartoe door Onze Minister van Justitie te benoemen commissie. Bij de wet worden nadere regelen gesteld omtrent de wijze van samenstelling en de werkwijze van de commissies."

(Terjemahan harfiahnya: Suatu peraturan standar atau perjanjian baku ditetapkan, diubah dan dicabut oleh suatu komite untuk ditunjuk untuk tujuan ini oleh Menteri Kehakiman kita. Undang-undang menetapkan aturan lebih lanjut tentang cara komposisi dan metode kerja komite.)

Komisi ini diberi kewenangan yang sangat besar antara lain untuk menetapkan, merubah dan mencabut suatu perjanjian baku yang dikenal dengan istilah standaardregeling atau standard contract. ${ }^{13}$ Hal ini sangat efektif untuk memberikan perlindungan kepada konsumen mengingat dengan perkembangan kemajuan teknologi yang secara masif terus berkembang.

Sehingga, komisi yang dibentuk di negeri Belanda tersebut tidak hanya melakukan pengawasan terhadap pencantuman klausula baku, tetapi sudah melebihi dengan memberikan penilaian terhadap perjanjian baku itu sendiri. Ketika terdapat perjanjian baku yang tidak sesuai dengan ketentuan yang berlaku, maka komisi dapat merubah bahkan mencabut perjanjian baku tersebut.

Perlindungan preventif ini bertujuan agar pelaku usaha aplikasi memenuhi hakhak konsumen dengan menjamin memberikan ganti rugi kepada konsumen apabila melakukan pelanggaran dan juga peran pemerintah agar mengawasi dan memastikan pelaku usaha mematuhi ketentuan yang telah diatur dalam Undang-Undang Perlindungan Konsumen.

\section{b. Perlindungan Hukum Represif}

Hukum berfungsi sebagai perlindungan kepentingan manusia oleh karena itulah hukum memang harus dijalankan. ${ }^{14}$ Perlindungan represif dalam UU No. 8 Tahun 1999 terkait pengalihan data pribadi konsumen dalam menggunakan layanan jasa transportasi online berbasis aplikasi dapat dilakukan dengan melibatkan peran pemerintah dalam memberikan perlindungan hukum akibat kerugian yang dialami

${ }^{13}$ Henry P. Panggabean, Penyalahgunaan Keadaan (Misbruik van Omstandigheden) Sebagai Alasan (Baru) Untuk Pembatalan Perjanjian (Berbagai Perkembangan Hukum Di Belanda), (Yogyakarta : Liberty, 1991), hlm. 68.

${ }^{14}$ Eman Ramelan, Perlindungan Hukum Bagi Konsumen, (Yogyakarta : Laksbang Mediatama, 2014), hlm. 19 . 
oleh konsumen dalam mengkonsumsi barang dan atau jasa. Perlindungan ini menitikberatkan dengan adanya sanksi atas perbuatan pelaku usaha yang tidak memenuhi hak-hak konsumen dengan berupa sanksi perdata dan sanksi pidana. Penanganan perlindungan hukumnya dapat dilalui dengan dua cara yakni, litigasi (melalui pengadilan) atau non litigasi (penyelesaian di luar pengadilan). Penyelesaian melalui litigasi sebagaimana ketentuan dalam Pasal 48 untuk mengacu pada ketentuan peradilan umum. Pengajuan gugatan menurut Undang-Undang Nomor 2 Tahun 1986 Tentang Peradilan Umum terbagi menjadi tiga tingkatan, yakni pengadilan Negeri, Pengadilan Tinggi, dan terakhir Mahkamah Agung. Sedangkan penyelesaian di luar pengadilan dapat melalui Badan Penyelesaian Sengketa Konsume (BPSK) sesuai dengan Pasal 47 UU No. 8 Tahun 1999.

Sebagaimana sanksi perdata apabila konsumen telah melanggar dengan mencantumkan klausula baku dalam perjanjiannya maka sesuai dengan ketentuan dalam Pasal 18 Ayat (1) a UU No. 8 Tahun 1999. Hal ini sebagaimana dalam Ketentuan kebijakan privasi dalam Go-jek yang menyatakan pengalihan data pribadi konsumen yang merupakan tanggung jawab yang harus dipenuhi oleh pelaku usaha aplikasi. Dengan mengacu pada ketentuan di atas ini yang telah melanggar ketentuan klausula baku yang disebutkan dalam Pasal 18 Ayat (1) UU No. 8 Tahun 1999 maka ketentuan selanjutnya dalam Pasal 18 Ayat 3.

Sesuai dengan ketentuan di atas bahwa pelaku usaha aplikasi yang telah menetapkan klausula baku yang sesuai dengan Pasal di atas maka Pelaku usaha aplikasi dalam dokumen atau perjanjiannya dapat dinyatakan batal demi hukum. Kemudian Pelaku usaha berkewajiban melakukan penyesuaian klausula kontrak yang menyimpang dengan aturan yang berlaku.

Beragam upaya perlindungan konsumen atas pemberlakuan kontrak baku yang tereduksi dalam penerapan berbagai prinsip perlindungan baik mulai dari prinsip perjanjian, prinsip mengenai kedudukan konsumen dengan pelaku usaha, serta prinsip tanggung jawab diarahkan untuk menciptakan suatu kepastian hukum yang sifatnya holistic protection yakni perlindungan dari hulu hingga hilir. Hulu maksudnya legalitas dalam tahapan awal kontrak (pra contract dan contractual) seperti mengenai kesepakatan maupun penentuan substansi kontrak yang disesuaikan dengan ketentuan perundang-undangan sedangkan hilir sebagai tahapan pelaksanaan kontrak (post contract) yang dijewantahkan dalam bentuk konsekuensi bertanggung jawab atas penerapan kontrak baku yang berklausula eksonerasi. Akan tetapi apabila suatu kontrak baku sudah dikategorikan menempatkan kondisi yang tidak seimbang (berpotensi merugikan) maka untuk mengatasi hal tersebut terdapat beberapa upaya pemulihan (restitutif), yaitu: ${ }^{15}$

15 Herlien Budiono, Asas Keseimbangan Bagi Hukum Perjanjian Indonesia, Hukum Perjanjian Berlandaskan Asas-Asas Wigati Indonesia, (Bandung : PT. Citra Aditya Bakti, 2006), hlm. 487. 


\section{1) Negosiai Ulang}

Negosiasi ulang dimungkinkan pada perjanjian yang mengalami suatu keadaan yang tidak terduga (overmacht). Negosiasi ulang dalam rangka memperbaiki perjanjian dapat dilakukan melalui perdamaian (schikking), mediasi, atau atas campur tangan hakim.

2) Penyesuaian

Dalam hal terjadi suatu sebab mengakibatkan pemenuhan perjanjian masih dimungkinkan tetapi bagi pelaku usaha aplikasi sendiri hal tersebut sudah tidak lagi bermakna, maka pembatalan perjanjian merupakan solusi yang tepat.

Dalam hal terjadi cacat kehendak karena adanya ancaman (dwang) atau penipuan (bedrog), maka kewenangan untuk mengubah perjanjian tidak berlaku Pihak yang dikorbankan dalam hal ini memiliki pilihan untuk memutuskan hubungan hukum termasuk termasuk juga mengenai penawaran penghapusan kerugian yang ditanggung korban atau mengajukan gugatan melawan hukum.

3) Pengakhiran

Pengakhiran perjanjian secara normatif dikategorikan dalam bentuk dapat dibatalkan atau batal demi hukum. pembagian jenis kebatalan ini merujuk pada ketentuan pasal 1320 KUHPerdata dan pasal 1337 KUHPerdata. Agar timbul peran ganti rugi sebagai corak keperdataan yang merupakan instrumen dalam memulihkan kembali hubungan hukum para pihak yag telah terganggu sebelumnya.

Sedangkan tanggung jawab secara pidana dalam Undang-Undang Perlindungan Konsumen mengatur mengenai pertanggungjawaban pidana merujuk pada ketentuan Pasal 61 sampai dengan Pasal 63 UU No. 8 Tahun 1999. Pasal 61 menyatakan bahwa "penuntutan pidana dapat dilakukan terhadap pelaku usaha dan/atau pengurusnya." Ketentuan ini memperlihatkan suatu bentuk pertanggungjawaban pidana yang tidak hanya dapat dikenakan kepada pengurus tetapi juga kepada perusahaan. Hal ini menurut Nurmadjito merupakan upaya yang bertujuan menciptakan sistem bagi perlindungan konsumen. Melalui ketentuan Pasal ini perusahaan dinyatakan sebagai subjek hukum pidana. ${ }^{16}$

Selanjutnya dalam ketentuan pasal 62 ayat (1) UU No. 8 Tahun 1999, memberlakukan dua aturan hukum sesuai dengan tingkat pelanggaran yang dilakukan oleh pelaku usaha, yaitu pelanggaran yang mengakibatkan luka berat, sakit berat, cacat tetap, atau kematian yang dikualifikasikan sebagai tindak pidana kejahatan sehingga dalam hal ini diberlakukan ketentuan hukum pidana yang diatur dalam KUHP, sementara di luar dari tingkat pelanggaran tersebut berlaku ketentuan pidana

\footnotetext{
${ }^{16}$ Ahmadi Miru \& Sutarman Yodo, Op.Cit, hlm. 276.
} 
sebagaimana yang termuat dalam Undang-Undang Perlindungan Konsumen. Tindak lanjut dari pelaksanaan sanksi hukum yang termuat dalam Pasal 62 ini secara normatif lebih ditingkatkan lagi pada ketentuan Pasal 63 UU No. 8 Tahun 1999, yang menyatakan bahwa :

Terhadap sanksi pidana yang dimaksud dalam Pasal 62, dapat dijatuhkan hukuman tambahan, berupa:

a. Perampasan barang tertentu

b. Pengumuman keputusan hukum

c. Pembayaran ganti rugi

d. Perintah penghentian kegiatan tertentu yang menyebabkan timbulnya kerugian konsumen

e. Kewajiban penarikan barang dari peredaran

f. Pencabutan izin usaha.

\section{E. PENUTUP}

Berdasarkan pembahasan terhadap penelitian sebagaimana dikemukakan, kesimpulan yang dapat ditarik adalah sebagai berikut:

1. Klausula dalam perjanjian transportasi online sebagaimana dalam kebijakan privasinya melanggar ketentuan dalam Pasal 18 Ayat (1) UU No. 8 Tahun 1999, dengan adanya klausula eksonerasi terhadap data pribadi konsumen pelaku usaha mengalihkan pertangungjawaban yang seharusnya menjadi tanggung jawab pelaku usaha aplikasi. Klausula eksonerasi dalam perjanjian transportasi online ini mengindikasikan adanya ketidaksesuaian dengan kewajiban pelaku usaha aplikasi terkait data pribadi yang seharusnya dilindungi oleh pelaku usaha aplikasi agar konsumen merasa aman dan nyaman dalam menggunakan jasa transportasi online.

2. Perlindungan hukum bagi konsumen mengenai data pribadi dalam klausula eksonerasi ini secara preventif, dalam UU No. 8 Tahun 1999 dengan adanya pengawasan dan tanggung jawab dari pemerintah melalui menteri yang terkait untuk memenuhi klausula dalam sebuah perjanjian, terlebih dengan kemajuan teknologi ini perlu pengawasan yang lebih ketat sehingga tidak menimbulkan kerugian bagi konsumen. Sedangkan secara represif klausula eksonerasi secara perdata dalam UU No. 8 Tahun 1999 menjadi batal demi hukum, sehingga pelaku usaha harus merevisi dan mengganti kerugian kepada konsumen. Selain itu dapat juga ditempuh dengan melakukan negosiasi ulang, penyesuaian hingga apabila tidak mendapatkan kesepakatan maka dapat dibatalkan. Adapun secara pidana terkait klausula eksonerasi dalam data pribadi konsumen maka dapat dikenakan sanksi berupa pidana penjara paling lama 5 tahun atau pidana denda 2 miliar rupiah.

\section{DAFTAR PUSTAKA}


Ahmadi Miru \& Sutarman Yodo, Hukum Perlindungan Konsumen, Raja Grafindo Persada, Jakarta: 2008.

Eman Ramelan, Perlindungan Hukum Bagi Konsumen, Laksbang Mediatama, Yogyakarta: 2014.

Grab, Pengumpulan Data Pribadi, Kebijakan Privasi Grab, (online), https://www.grab.com/id/privacy/ di akses pada 15 Oktober 2018.

Henry P. Panggabean, Penyalahgunaan Keadaan (Misbruik van Omstandigheden) Sebagai Alasan (Baru) Untuk Pembatalan Perjanjian (Berbagai Perkembangan Hukum Di Belanda), Liberty, Yogyakarta: 1991.

Herlien Budiono, Asas Keseimbangan Bagi Hukum Perjanjian Indonesia, Hukum Perjanjian Berlandaskan Asas-Asas Wigati Indonesia, PT. Citra Aditya Bakti, Bandung: 2006.

Johnny Ibrahim, Teori \& Metodologi Penelitian Hukum Normatif, Bayumedia Publishing, Malang: 2006

Peter Mahmud Marzuki, Penelitian Hukum, Kencana Prenada Media Group, Jakarta: 2005.

R. Subekti, Hukum Perjanjian, PT.Intermessa, Jakarta: 1996.

Undang-Undang Dasar Negara Republik Indonesia 1945.

Undang-Undang Nomor 11 Tahun 2008 Tentang Informasi dan Transaksi Elektronik (Lembaran Negara Republik Indonesia Tahun 2008 Nomor 58) (Tambahan Lembaran Negara Republik Indonesia Nomor 4843)

Undang-Undang Nomor 19 Tahun 2016 Tentang Perubahan Atas Undang-Undang Nomor 11 Tahun 2008 Tentang Informasi dan Transaksi Elektronik (Lembaran Negara Republik Indonesia Tahun 2016 Nomor 251) (Tambahan Lembaran Negara Republik Indonesia Nomor 5952)

Undang-Undang Nomor 8 Tahun 1999 Tentang Perlindungan Konsumen (Lembaran Negara Republik Indonesia Tahun 1999 Nomor 42) (Tambahan Lembaran Negara Republik Indonesia Nomor 3821) 